\title{
Semantic Remotivation and Idiomatization through Functional Recontexualization: A Corpus-based Study on the History of German zeitnah(e) 'Promptly; Very Soon'
}

\author{
Anneliese Kuhle \\ Correspondence: Anneliese Kuhle, Institute for English Language and Literature, Free University Berlin, \\ Habelschwerdter Allee 45, 14195 Berlin, Germany
}

Received: June 23, 2015 Accepted: July 7, 2015 Online Published: August 12, 2015

doi:10.11114/smc.v3i2.893

URL: http://dx.doi.org/10.11114/smc.v3i2.893

\begin{abstract}
This paper deals with the question of what concepts of linguistic change can best capture the recent development undergone by German zeitnah(e) lit. 'time+near'. I will argue that the notions of semantic remotivation, idiomatization and recontextualization provide the most useful insights into the observed phenomenon. On a more critical note, I will argue that recontextualization should be allowed a broader definition than attributed to it in current linguistic research. I contend that it is misleading to restrict the term to special instances of pragmatic connotation and to thereby suggest that other meaning shifts are less grounded on the principle of historical contextualization.
\end{abstract}

Keywords: semantic-pragmatic change, semantic remotivation, idiomatization, functional recontexualization, temporal deixis, usage-based approach

\section{Introduction}

Wortbildungen sind ausnahmslos in ihrer Bildeweise offen für unterschiedliche Deutungen. Sie bekommen die maßgebliche im Gebrauch, wie es für alle Wörter gilt. (Eroms, 2010, p. 264)

'Word formations are invariably open to different interpretations. They receive the decisive one through their usage, as this is true of all words.' (Transl. by A. K.)

This paper deals with the question of what linguistic concepts of semantic-pragmatic change can provide the most adequate explanation for the recent historical development undergone by German zeitnah(e) 'promptly; very soon'. I will argue that the general framework of linguistic strengthening processes as defined in works by Rüdiger Harnisch (Harnisch, 2004, 2010) provides the most illuminating insights into the observed phenomenon. It does not only allow for various usage-based, pragmatic factors to play a role but also highlights different directionalities and intermediate stages of change not easily subsumed under more conventional conceptions of language change, in particular, lexicalization and grammaticalization. More specifically, I will argue that the concepts of semantic remotivation, idiomatization and recontextualization are useful concepts for capturing the emergence of zeitnah(e) as a temporal-deictic expression. On a more critical note, I will argue that recontextualization should be allowed a broader definition than attributed to it in current linguistic research (Harnisch, 2010). This would have the advantage that it could serve as an ingredient to other concepts of change, rather than just being reserved for special instances of pragmatic connotation.

In the sections below, I will proceed as follows: In Section 2.1, I introduce German zeitnah(e) as a determinative compound with two meaning variants, one metaphorical the other temporal-deictic. Subsequently, in Section 2.2, I turn to a corpus-linguistic case study. In Section 2.3, I give a concise outline of the history of this form spanning the past sixty years, relying on a limited set of data drawn from the DWDS text corpus DIE ZEIT. In the discussion, Section 3, I argue that the concepts of semantic remotivation, idiomatization and recontextualization (defined in a broad and narrow sense) are useful concepts for capturing the historical development of zeitnah(e) into and as a time-deictic expression. In Section 4, I briefly conclude my findings. 


\section{German zeitnah(e): Its Meaning and History since 1946}

\subsection{A Determinative Compound with Two Meaning Variants}

German zeitnah(e) is an adjectival compound consisting of the nominal element zeit- (< Zeit n. 'time') and the adjectival element -nah(e) $(<n a h(e)$ adj. 'near; close to'). Following the classification in Eichinger (2000, p. 117, p. 123) and Fleischer and Barz (2012, p. 322-323), this composition of a simplex nominal modifier (zeit-) and an adjectival head (-nah) qualifies as determinative compound (Determinativkompositum). The compositional pattern is analogous to various other formations in Present Day German such as, for instance, bildungsnah 'education.near' ('well-educated'), realitätsnah 'reality.near' ('realistic'), ortsnah 'location.near' ('local'), volksnah 'people.near' ('down-to-earth; in touch with the people'), or praxisnah 'practice.near' ('practical; with practical orientation'). ${ }^{1}$

Both constituents of the compound are still productively in use as independent lexical items (noun and adjective, respectively) and as such both have various meaning variants in current usage. The noun Zeit is used to denote various concepts of time, including the dynamic-durational meaning of time as spanning seconds, minutes, hours, days etc. (die Zeit vergeht schnell '[the] time goes by fast'; das war eine schöne Zeit 'that was a great time'), as being punctual and referring to points in time (Um welche Zeit trefft ihr euch? 'at what time do you meet'), as well as a more indeterminate, generic or meta-durational conceptualization of time as encompassing an historical age/era/epoch (in der heutigen Zeit 'in modern times'; Stil einer Zeit 'style of a certain time period') (WDG Online). The adjectival meaning of nah(e) 'near; close to; not far from', on the other hand, is divided into three major domains: (1) spatial proximity (die nahe Stadt 'the nearby town'), (2) temporal proximity (in naher Zukunft 'in the near future') and (3) metaphorical proximity (ein naher Verwandter 'a close relation') (WDG Online).

The contemporary meaning and use of zeitnah(e) displays two different meaning variants which incidentally correlate with two different meaning variants of both the nominal constituent Zeit 'time' and the adjectival constituent nah(e) (see above). One meaning variant of zeitnah(e), which often receives lexicographic entries in dictionaries of contemporary German (WDG, p. 4432; GWDS, p. 4604; BWDWB, p. 817), draws on the generic meaning of Zeit in the sense of 'era/epoch/age' and the metaphorical meaning of nah(e) in the sense of 'close/similar to': (i) zeitnah(e) 'timely; contemporary; topical; modern' (= close to/representative of a time period). Examples include phrases like ein zeinahes Theaterstück 'a contemporary modern play' and eine zeitnahe Aufführung 'a contemporary performance' (WDG, $\mathrm{p}$. 4432). Many of these usages show zeitnahe in attributive function though it may also be used in predicative and adverbial function (cf. Section 2.2). The other meaning variant of zeitnah(e), by contrast, draws on the dynamic-durational meaning of Zeit on scales measuring seconds, minutes, days, months etc., and is thus temporal-deictic in meaning (Levinson, 2009, p. 73-74): (ii) zeitnah(e) 'timely; promptly; very soon; temporally close to' (= temporally close to some point in time X). The WDG and GWDS do not (yet) provide an entry for this meaning variant but other (online) dictionaries, such as Wiktionary, do acknowledge its current usage for Present Day German $(<$ de.wiktionary.org/wiki/zeitnah $>)$. A sentence example from Wiktionary is the following: Der Beschluss sollte zeitnah umgesetzt werden; inzwischen ist aber schon wieder viel Zeit verstrichen 'the resolution was supposed to be carried out

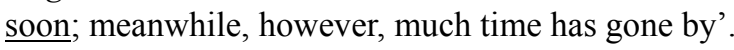

\subsection{A Diachronic Study in the DWDS Text Corpus DIE ZEIT}

The DWDS Corpus is a publically accessible electronic data base which was first erected 2000-2003 and has since then been continuously expanded (Geyken, 2006). It is expressly designed for linguistic research purposes and coded according to linguistic annotation conventions involving tokens and part-of-speech tagging. Starting from the introductory DWDS platform (<www.dwds.de/>) I conducted a simple search of the lemma "zeitnah". Due to its prominence in public discourse, I concentrated my search on the concordances listed in the magazine corpus DIE ZEIT. The corpus contains all Zeit-issues that were published online between 1946 and 2009 [February 2014], and has a total size of 460 million tokens. The search for "zeitnah" yielded 265 concordances (excluding repetitions), which included adjectival as well as adverbial token occurrences (and also one or two nominalizations).

\subsection{Findings: The Spectrum of Functional Variants over Time}

In this section, I will illustrate in more detail the different functional variants as subsumed under VARIANT 1, VARIANT 2 and VARIANT 3, respectively. To capture the spectrum of functional variants over time, and to refer to concrete numbers, I will rely on Figure 1 throughout the entire section.

\footnotetext{
${ }^{1}$ Some of these compounds, such as bildung-s-nah and realität-s-nah, involve a linking consonant (-s-) between the compositional elements; others, like zeit-nah, körper-nah and praxis-nah, do not involve such a phonological ligand (for a discussion of 'Fugenelemente' in German compounds, see Fleischer \& Barz, 2012, p. 15-16, p. 66-67).
} 


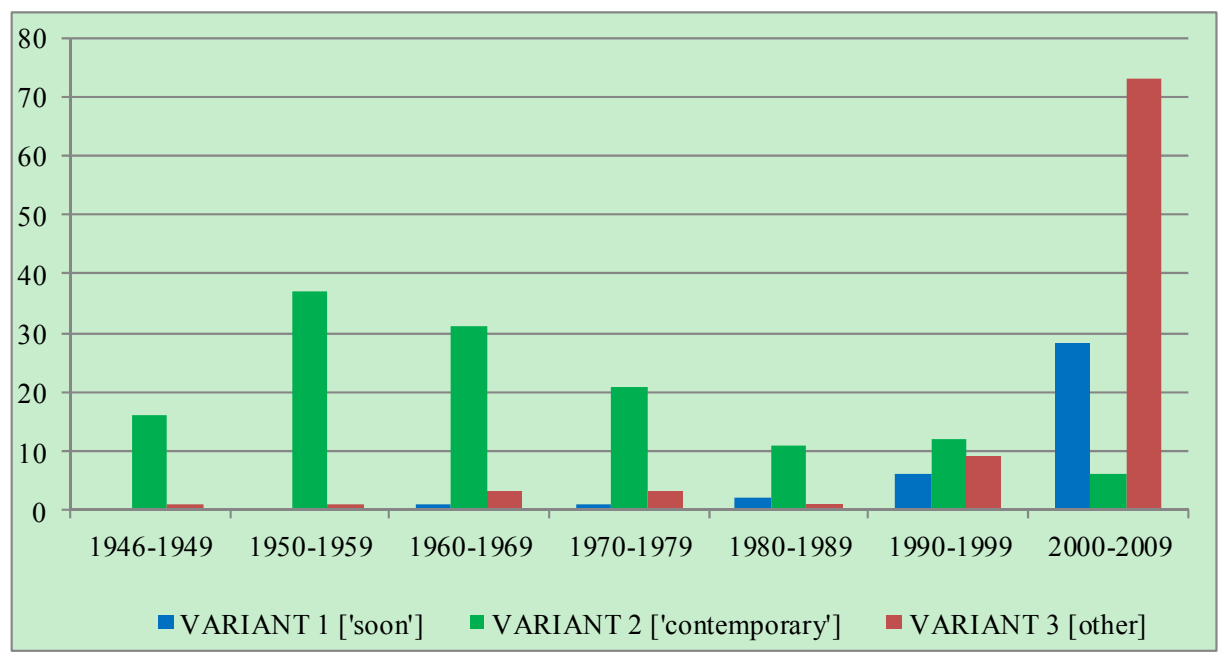

Figure 1. Absolute frequencies of functional variants of "zeitnah(e)" as attested in the DWDS ZEIT corpus between 1946 and 2009.

The frequencies for each variant are arranged by decade (beginning with half a decade 1946-1949, then proceeding with full decades until 2009). The numbers given along the vertical axis indicate absolute numbers of token occurrences, notwithstanding repetitions. Table 1 in the Appendix documents the classification of all collected concordances of this search.

\subsubsection{Findings for VARIANT 1}

The statistics suggest that the increased usage of zeitnah as a time adverb in the sense of 'soon; in the near future' (V1) is a recent development - a phenomenon of the $21^{\text {st }}$ century. Between 2000 and 2009, usages such as those given in Example 1 are thus found recurrently in my data base. Given their context of utterance, they are most suitably translated by English expressions like soon, very soon, shortly or in the near future. These near-future-oriented meanings can be attested for both adjectival and adverbial uses of zeitnah(e), but the latter are more frequent. In the sentence below, the token exemplifies the adverbial use.

(1) Müller: Ich darf zunächst einmal sagen, dass sich die Einigkeit natürlich darauf bezogen hat, dass es zwar Dinge gibt, die wir zeitnah angehen können, wie die nochmalige Überarbeitung des Waffengesetzes, dass es darüber hinaus aber sehr grundsätzliche Fragen gibt, deren Bearbeitung längere Zeit in Anspruch nehmen wird [...]. (DWDS, DIE ZEIT, Treffer 101, Die Zeit, 07.05.2002, Nr. 19) 'Müller: Let me first of all say that the [reached] consensus of course referred to the fact that there do exist things which we can approach shortly [within the near future], such as [for instance] the renewed revision of the gun control law; that however there also exist issues of a very fundamental nature which require more time $[\ldots]$.'

As is indicated in Figure 1, for the time period 2000-2009, I counted a little less than 30 tokens exemplifying this time-deictic (near-future-oriented) function of zeitnah(e). This number stands in clear contrast to the rather scarce occurrence of V1 in the preceding decades, though interestingly enough it is not completely absent either. It occurs more or less sporadically throughout the decades, but does not considerably gain in numbers until the late 1990s. The earliest arguable example dates back to the year 1960 and attests an adjectival use (die zeitnahe Behandlung von Korrputionsfällen transl. 'the speedy handling of cases of corruption'); another early example is from 1968 and attests an adverbial use (eine ordungsgemäße Buchführung muss alle Geschäftsvorfälle [...] so zeitnah wie möglich festhalten transl. 'a proper bookkeeping must register all business transactions [...] as promptly [soon] as possible'). As was mentioned above, by far most token occurrences of $\mathrm{V} 1$ are instances of the adverbial form zeitnah (usually realized without $[0] /<\mathrm{e}>$ ); however, I did find a few attestations of adjectival zeitnahe which seemed close semantic equivalents of the adverbial meaning. Examples include phrases like die zeitnahe Klärung aufgeworfener Fragen 'the speedy clarification of raised issues', die zeitnahe Veröffentlichung von Spenden 'the speedy publishing of donations' and Hinweise auf zeitnahe Anschläge in Deutschland 'indications of imminent terror attacks in Germany'.

\subsubsection{Findings for VARIANT 2}

With respect to the metaphorical-descriptive use of zeitnah(e) in the broad sense of 'contemporary' (V2), we may first of all note that it is present throughout the second half of the $20^{\text {th }}$ century and also persists in the journalistic writing of Die Zeit in the early $21^{\text {st }}$ century. However, the relative differences in frequency for each decade (see Figure 1) do 
suggest a slight decrease in the usage of this variant over time. ${ }^{2}$ The example in 2 illustrates typical occurrences of adjectival zeitnah(e) in the specific sense of 'representative of the present time' and/or 'time-critical'.

(2) Andererseits sollte man nicht übersehen, dass in fast allen vorgelesenen Prosa[-] wie Lyrik- Versuchen moralische, psychologische und zeitkritische, jedenfalls auffällig zeitnahe Motive vorherrschen. (DWDS, DIE ZEIT, Treffer 210, Die Zeit, 03.12.1965, Nr. 49) 'On the other hand, one should not overlook [the fact] that in almost all read-out attempts at prose and lyrics, moral, psychological and time-critical, at any rate conspicuously contemporary motives do prevail.'

Other token occurrences also illustrate the use of zeitnahe in the wider sense of 'contemporary', yet more in the specific senses of 'topical', 'up to date' or 'trendy' (German aktuell, topaktuell, modisch), and thus less in association with meaning components like 'time-critical' (German zeitkritisch) or 'representative of the present times/era' (German zeitgenössisch). In the current data analysis, all these metaphorical-descriptive variants were subsumed under V2; however, it should be kept in mind that they do yet carry different meanings depending on how speakers apply them in context, that is, in combination with specific collocates or in discourse more generally.

\subsubsection{Findings for VARIANT 3}

Finally, we must disentangle the findings for VARIANT 3. The initial approach to the data analysis had been to draw the three-way distinction between temporal uses in the broad sense of 'soon' (German bald, in Kürze etc.) (V1), lexical uses in the broad sense of 'contemporary' (German zeitgenössisch, aktuell etc.) (V2), and still other uses (V3) which could be neither subsumed under V1 nor V2. However, this "other" category, V3, proved to be much more varying and numerous than anticipated. As we can see from Figure 1, especially the most recent time interval 2000-2009 shows a marked increase in usages of zeitnah(e) which fall into this domain (more than 70 token occurrences as opposed to less than 10 in previous decades).

Hence, in a second approach, I further refined my semantic criteria for tokens of zeitnah(e) as they were pooled under V3. Several (sub)variants turned out to receive recurrent attestations in the ZEIT corpus, some of which I will exemplify below. A first conspicuous variant was the temporal-deictic use of zeitnah(e) in the sense of '(very) close to'. Some occurrences (in particular adjectival usages) of this variant were reminiscent of the immediate present-time reference also encoded by the lexical variant 'contemporary', though typically without those other meaning components otherwise also contained by that form ('time-critical', 'modern', 'topical'). In Example 3 below, zeitnahe seems to refer first and foremost to some time period in terms of temporal proximity, and does not necessarily imply any of the other meaning aspects typical of V2 members:

(3) Terror gehörte durchweg zur Strategie der Nationalen Befreiungsfront. Gewiss wurde der Vietcong vielerorts als Volksvertretung anerkannt, etwa in der Provinz Quang Ngai, über die es in einem zeitnahen Bericht der U.S. Army hieß: „Der Vietcong ist hier nichts Eigenes. Der Vietcong ist das Volk.” (DWDS, DIE ZEIT, Treffer 40, Die Zeit, 08.01.2008, Nr. 2) 'Terror continuously formed part of the strategy of the National Liberation Front. In many places the Vietcong was surely recognized as parliament, as for instance in the province of Quang Ngai, of which a contemporary report of the U.S. Army stated: "The Vietcong is nothing independent here. The Vietcong is the people."

Other uses (often adverbial) are less reminiscent of V2. For example, one type of use establishes time-deictic relations between different events, neither of which must be anchored to a present. This temporal use is best translated using the English preposition close to ('before or after'):

(4) Aber Schmid versichert, dass der Film noch kommt: „Frau Mendelsohn ist gebeten, den Film zu überarbeiten. Der SWR will ihn zusammen mit einer Diskussion zeitnah zur Veröffentlichung der deutschen Ausgabe von Norman Finkelsteins Buch zeigen. (DWDS, DIE ZEIT, Treffer 111, Die Zeit, 06.02.2001, Nr. 6) 'But Schmid assures that the film will yet come out: "Mrs. Mendelsohn has been asked to edit the film. The SWR plans to screen it together with a discussion close to [shortly before or after] the publication of the German edition of Norman Finkelstein's book.'

\footnotetext{
2 The reasons for this decline should however be treated with caution. First of all, instances of VARIANT 2 do still occur in the new millennium (cf. Fig. 1), and just as before, most of these usages occur in discourse concerning sociopolitical/cultural issues. Second, it is not at all clear whether the decrease in occurrences might not have something to with the overall selection of subject matters (hot topics) by the editors of Die Zeit. It is thus at least possible that the decline in frequency is a mere artifact of magazine editing rather than journalistic writing more generally.
} 
Even more conspicuous are temporal meanings like 'promptly', 'immediately', 'quickly' or 'in a timely manner'. Though still scarce throughout the 1950s and $-60 \mathrm{~s}$, it is a variant which becomes more frequent towards the end of the $20^{\text {th }}$ century. Typical examples include the following:

(5) Wir werden uns bemühen, unsere Investitionen so zeitnah wie irgend möglich der Nachfrage anzupassen [...]. (DWDS, DIE ZEIT, Treffer 197, Die Zeit, 17.07.1970, Nr. 29) 'We will endeavor to adjust the investments to the demand as quickly as possible [...].'

(6) So konnte sich der DFB in den letzten Wochen sicher sein, dass alle Nachrichten ihre Empfänger zeitnah erreichten. (DWDS, DIE ZEIT, Treffer 31, Die Zeit, 30.07.2008) 'Over the past few weeks, the DFB [German Football Association] could thus be certain that all news would be timely obtained by their receivers.'

Going simply by token number in the collected data set, the initial context of emergence of this functional variant of zeitnah(e) is the German investment and banking jargon. During this early period, its use seems to have been established quickly within several discourse areas, most notably talk in and about public services such as TV broadcast, contract management or medical healthcare. This development applies equally to the adverbial and adjectival function of zeitnah(e). Only later, 2000-2009, does this variant also begin to enter the political jargon on a more regular basis, such that journalists either quote politicians directly, or adopt the use of this term themselves to comment on political decision-making (for examples, see Section 3.3). ${ }^{3}$

As can be seen from the above examples, some of the temporal usages of zeitnah(e) already begin to blend into the near-future-oriented usages of zeitnah(e) as they were previously defined as VARIANT 1. In other words, context of usage plays an important part in interpreting the temporal readings of this form, and many in-between cases can be found which make zeitnah(e) look neither fish nor flesh if judged against the rigid categorizations of V1-V3. We will return to this issue in our discussion below.

\section{Discussion: Semantic-Pragmatic Remotivation and Idiomatization through Functional Recontextualization}

In this section I attempt a synthesis of different theoretical concepts in order to capture the major characteristics of the historical development undergone by the compositional form zeitnah(e) over past decades. In this analysis, I follow the recent work by Rüdiger Harnisch as presented in Harnisch (2010). However, instead of considering semantic remotivation and idiomatization, on the one hand, and recontextualization, on the other, as fundamentally different processes of change (and thus separately from one another), I seek to emphasize that (functional) recontexualization already and inevitably plays an important part in both semantic remotivation and idiomatization. On principle, this consideration of context and re-contextualized usages in functional approaches to language change is anything but new (Kemmer \& Barlow, 2000; Traugott, 2012; von Mengden \& Coussé, 2014). Nevertheless, I contend that it is misleading to restrict the term recontexualization only to instances of pragmatic connotation (cf. Section 3.3.) and to thereby suggest that other processes of semantic-pragmatic change are not grounded on the very same principle of historical contextualization.

\subsection{Semantic Remotivation}

The meaning shift from Variant 2 ('contemporary') to Variants 1 and 3 ('promptly, timely, very soon') qualifies as a case of semantic remotivation. Harnisch (2010) subsumes this concept under the domain of linguistic strengthening (sprachliche Verstärkung) which is defined as semantic-pragmatic change which neither involves the idiomatization of lexical meaning (lexicalization) nor the loss of structural independence or semantic complexity as is characteristic of grammaticalization (Harnisch 2010, p. 18-19). Instead, in positive terms, the process is conceptualized as a kind of horizontal or inverse change, where the structural complexity of a form is either maintained or increased, and where, by some process of iconic or analogical transfer, the conceptual meaning of a form is replaced by another conceptual meaning not implicitly contained by the former (Harnisch 2010, p. 3-4). As a general rule, the initial preservation (or sometimes even increase) of structural complexity is necessary for this process of change, as the semantic-pragmatic innovation which is achieved in such cases does crucially depend on the structural transparency and iconicity of the recruited material in relation to the source material from which the semantic innovation originates.

The case of zeitnah(e) fits this dynamic concept very well. The compound form has undergone a semantic change without any overt loss in either structural complexity or compositional transparency. Its compositional meaning has been reanalyzed from (A) zeitnah(e) 'close to a certain time period (= present times, historical era) in terms of content, criticism or style' to (B) zeitnah(e) 'close to a certain point in time (= moment of utterance, past or future event) in

\footnotetext{
${ }^{3}$ The observations in this paragraph are also confirmed by the journalist Bastian Sick in Sick (2006).
} 
terms of temporal duration (= minutes, hours, days etc.)'. Put differently, it has been reanalyzed from a composition between zeit- 'time era, zeitgeist' and -nah(e) 'metaphorical proximity' to a novel composition consisting of zeit- 'time (= minutes, hours etc.)' and -nah(e) '(temporal) proximity'. It is assumed here that native speakers of German have no trouble identifying the compositional structure and meaning of the form, whether used as Variant 1, 2 or 3. This also applies to cases where the exact reading of the form is becoming more idiomatic (cf. Section 3.2 below).

Crucially, the meaning shift from stage (A) to stage (B) does not depend on a step-like modification of meaning concept (A). That is, we need not assume that the temporal-deictic meaning of zeitnah(e) ('temporally close to') derives historically from the metaphorical-descriptive meaning of zeitnah(e) ('contemporary') - even if we grant that etymologically the latter may have preceded the former. Instead, the compositional meaning of (B) can be much better motivated from its constituent elements zeit- and -nah(e) and their respective meaning variants as independent lexical items (cf. Section 2.1). Hence, the meaning formation (B) could have arisen independently, indeed even without the prior existence of the meaning formation (A). This assumption is also rendered plausible by the fact that the two constituents of the form (Zeit, nahe) and their meaning variants relevant for the formation of meaning concept (B) are still very much alive in present-day usage, and thus readily accessible in speakers' minds as source materials for the novel production of compositional forms.

Nevertheless, the consideration of context in the collected corpus data does provide more room for speculation. The etymologically older form (A) may still have had some impact on the novel formation (B), so that the latter's emergence may, at least partly, have been instigated by this earlier usage. These considerations are inspired by the discourse analyses given in Wengeler (2010) and Fill (2010), which highlight language users' versatility and deliberate creativity in blending different meaning components together in novel word formations, and which thus challenge any simplistic notion of semantic remotivation. The following example from the DWDS corpus data on zeitnah(e) illustrates how the notions of 'contemporariness', on the one hand, and 'temporal-deictic proximity', on the other hand, sometimes overlap in natural discourse, and how consequently speakers could, on principle, have come by the semantic remotivation of zeit + nah (e) through usage of the etymologically older form.

(7) Augenzeugenberichte gelten als schwierige Quellen, wenn das Ereignis weit zurückliegt. [...] Karlsch ist es jedoch gelungen, ein zeitnahes [,zeitlich nahes'] Schreiben der sowjetischen Militäraufklärung aufzutun. (DWDS, DIE ZEIT, Treffer 84, Die Zeit, 17.03.2005, Nr. 12) 'Eye witness reports are regarded as difficult sources when it comes to events long past. [...] Karlsch, however, has managed to find a contemporary ['temporally close'] letter from the Sowjet military intelligence.'

Given other circumstances of usage, the phrasal expression ein zeitnahes Schreiben (lit.) 'a contemporary piece of writing' would evoke the understanding that reference is made to a piece of writing typical and representative of a certain time period, either well exemplifying the spirit of the times or else providing a critical and apt assessment of a particular present times. Yet, given the specific context of utterance in the above example (see the underlined passage), we are to understand that zeitnahe first and foremost expresses temporal closeness to the events referred to, at the expense of those other, more metaphorical and conventionalized associations of the term.

To conclude, the emergence of zeitnah(e) as a temporal-deictic expression can be classified as an instance of semantic remotivation as defined in Harnisch (2010). This innovation may have originated in novel contexts of usage, that is, discourse contexts entirely removed from those associated with the usage of the etymologically older form. However, it is conceivable that the meaning shift occurred in contexts also typical of the earlier usage of this form. Pragmatic connotations of 'contemporariness' or 'timeliness', for example, which often cling to this form even in temporal-deictic usage, could thus be traces of this historical context of emergence. Related instances of such "hybrid" semantic remotivations in the formation of German compounds are discussed in Fill (2010).

\subsection{Idiomatization}

A further characteristic of zeitnah(e) as a temporal-deictic expression is the fact that it displays quite a number of context-dependent meaning variants otherwise still subsumable under temporal deixis. Thus, most if not all of the meaning variants discussed under VARIANT 1 ['soon'] and VARIANT 3 ['other'] in Section 2.3 share in common that they express temporal proximity of some sort, for which we do not need to assume independent conceptual roots. Yet, at the same time, we noted that this temporal-deictic meaning of zeitnah(e) receives different modifications depending on the context in which it is used. As VARIANT 1 it was characterized as near-future-oriented, implying not just temporal proximity but also future-orientedness in relation to some moment of utterance (cf. Ex. 1). Under VARIANT 3, in turn, we collected several other variations of the theme of temporal proximity, including for example the meaning variants 'promptly', 'timely' and 'close to event X' (cf. Ex. 3-6). In each case, we are dealing with time-deictic meanings of zeitnah(e) in the sense of 'temporally close to', yet between them these cases differ in that (a) different points in time are chosen as external reference points for its usage, and (b) different emotive qualifications apply (e.g., connotations of 
timeliness). In this respect, zeitnah(e) turns out to be a particularly flexible adverbial modifier whose temporal anchorage points are neither restricted to the moment of utterance nor to the points of time established throughout the discourse (cf. the distinction between 'speech-time-oriented' and 'context-oriented' time adverbs in Heidolph, Flämig \& Motsch 1981, p. 406). Neither is the form bound to any one temporal orientation like present, future or past, though the near-future-oriented meaning has considerably gained in frequency over the past 15 years (cf. Figure 1, Section 2.3).

These meaning shifts qualify as idiomatizations as defined, for example, in Lipka (2002, p. 112). According to this definition, idiomatization relates to complex linguistic units whose meaning no longer corresponds just to the meanings of their compositional parts. In the case of time-deictic zeitnah(e), at least some meaning variants qualify as idiomatic as their interpretations are not only reducible to the mere composition of zeit- and -nah(e). Instead, various additional meaning components (temporal-relational, emotive-expressive) are also forming part of their interpretation in context. Which of these have been added through contextualized usage and which of them must be considered remnants of the original context of emergence is not an easy question to answer, since in the previous section (Section 3.1) I argued that, already, different historical scenarios are conceivable for the primary step of semantic remotivation. The flexibility of speakers' and hearers' minds to semantically remotivate novel word formations in context is shown to be considerable (Wengeler, 2010; Fill, 2010), and hence, different historical scenarios and directionalities of change (idiomatization) are conceivable. Nevertheless, it is possible to give clear evidence that different contextualized usages can be held responsible for certain steps in semantic-pragmatic modification, and to thereby seek indirect proof that idiomatization by way of recontextualization has taken place. In the following, I want to illustrate this point with a few text examples.

(8) Auf Wunsch von Müntefering wurde aber das Treffen am Sonntag vereinbart, weil der SPD-Chef die Schlussberatungen zeitnah an die Vorstandssitzung der Sozialdemokraten legen wollte. (DWDS, DIE ZEIT, Treffer 73, Die Zeit, 13.10.2005, Nr. 41) 'As requested by Müntefering, however, the meeting was arranged on/for Sunday, because the SPD leader wanted to move the final consultations close [as close as possible] to the board meeting of the Social Democrats.'

In Example 8, zeitnah retains a similar meaning as in the attributive use (Ex. 7), however the addition of an adverbial phrase (underlined passage) has the modifying effect of relating this temporal proximity not to the present time, but rather to some other event located in a planned future. Were the same utterance made without the adverbial phrase, zeitnah would undoubtedly be interpreted in reference to the present und would be taken to mean something akin to lit. 'because the SPD leader wanted to schedule the final consultations for as close [to the present] as possible'. Example 4 in Section 2.3 gives a similar example of this kind.

Next, we turn to instances where recontextualization in language use can be shown to bring forth explicitly future-oriented interpretations of German zeitnah(e).

(9) Die Grundaufzeichnungen brauchen nicht unverzüglich gemacht zu werden, sind jedoch so zu machen, daß sie stets die Lage des Vermögens ersichtlich machen. Je größer der Beleganfall ist, um so mehr sind die Vorfälle zeitnah zu verbuchen, das heißt so bald als überhaupt möglich. (DWDS, DIE ZEIT, Treffer 202, Die Zeit, 13.09.1968, Nr. 37) 'The basic recordings need not be made promptly, but should be devised in a way such that they always provide access to the [current] state of the capital. The bigger the workload, however, the more it is necessary to record such incidences timely, that is, as soon as possible.'

What is interesting about the usage event in Example 9 is not only the fact that the speaker/writer chooses to add an additional explanatory phrase (that is, as soon as possible) as a way to bias the reading of zeitnah towards 'temporal immediacy' and 'very near future', but, also, that he/she chooses the word bald 'soon' over the possible alternative schnell 'quickly'. It may in this particular case have been an incidental rather than deliberate choice; however, in general, it should matter whether (when and how often) language users tend to contextualize the usage of zeitnah(e) with expressions like bald or demnächst 'soon; in the very near future' or rather schnell, zügig, rasch 'quick(ly); in a timely manner'. As these expressions encode different types of temporal modification (the latter being more dynamic and manner-oriented in meaning), it follows that if their different temporal modifications are implemented through context into the readings of zeitnah(e), they should also lead to different idiomatic outcomes. At present, it is difficult to decide which of these contextual readings has gained advantage over the other, because as I outlined in Section 2.3, many temporal uses of zeitnah(e), both adjectival and adverbial, are those conveying more dynamic meanings like 'prompt(ly)', 'quick(ly)' or 'timely' (V3). On the other hand, the recent rise of zeitnah in the sense of 'soon; shortly' (V1), including its appearance in daily discourse (see below), perhaps indicates an increasing incorporation of the more static, future-oriented meaning component 'soon'. Another, more moderate speculation would be that zeitnah(e) simply appears in different collocations and has its preferred readings in each of them.

To sum up, German zeitnah(e) provides a good example of a linguistic form whose recontextualizations into different contexts of utterance have led to the emergence of a wide spectrum of complex relational meanings within the broader 
domain of time deixis. In such instances of recontextualization, zeitnah(e) becomes, quite literally, loaded with additional meanings through context, such that it receives interpretations not originally carried by its compositional meaning (lit. 'time+near'). As we have seen, the spectrum of possible inferences for German zeitnah(e), which are recurrently attested in the corpus data, is anything but restricted. The form has been recontextualized repeatedly, and appears to be under way towards further entrenchment (Hopper, 1987), though some of its usages (e.g., in the senses of 'prompt(ly)' or 'very soon') are clearly more frequent and habitual than others. These meaning shifts qualify as idiomatizations as defined, for example, in Lipka (2002). Whether they also qualify as lexicalizations is open for future debate.

\subsection{Recontexualization}

In Harnisch (2010), recontexualization in the narrow sense is defined as pragmatic meaning change and is seen in opposition to semantic change (Harnisch 2010, p. 13-14). Like processes of semantic remotivation, it is also considered a type of strengthening; however, unlike them, its change is thought to derive from use in larger real-world contexts (historical events/eras), which evoke and shape certain expressive connotations but not the semantic (referential) content of an expression (Harnisch 2010, p. 14). This narrow conceptualization as a way to motivate and explain more pragmatic aspects of change also turns out to be useful for our present case study. As was outlined in Section 2, the temporal-deictic readings of zeitnah(e) emerged piece-meal only in very specific areas of thematic discourse throughout the second half of the $20^{\text {th }}$ century, most notably the investment and banking jargon. Sporadic temporal usages of zeitnah(e) also crop up in other places (e.g., columns on cultural life issues); however, by far most usages of adjectival and adverbial zeitnah(e) throughout the 1970s, $-80 \mathrm{~s}$ and $-90 \mathrm{~s}$ do occur in strong association with thematic issues dealing with economic policy-making and technical contracting arrangements. This indicates that earliest temporal usages of zeitnah(e) only gained currency in a very specific area of spoken/written discourse, concerning itself with a very specific subject matter to do with economic, public policy-making.

A later, yet conspicuous development then consisted in the transfer (further recontexualization) of zeitnah(e), especially as an adverbial form meaning 'shortly; very soon', into the political jargon (cf. Ex. 10). This development began throughout the 1990s, and increased significantly after 2000.

(10) [Quelle: Deutscher Bundestag] Einzelspenden über 50.000 Euro müssen dem Bundestagspräsidenten sofort gemeldet werden. Der ist wiederum verpflichtet, diese Informationen „zeitnah“ zu veröffentlichen. (DWDS, DIE ZEIT, Treffer 22, Die Zeit, 26.02.2009, Nr. 7) '[Source: German Bundestag] Individual donations exceeding 50.000 Euro must be reported to the president of the Bundestag [Federal Parliament] immediately. $\mathrm{He}$ in turn is duty bound to publish this information "shortly afterwards" [in a timely manner].'

The precise motivations for the transfer and increase in usage are not clear from the analyzed corpus data. However, there are a few possibilities which we might consider. First, political agendas are continuously influenced by economic policy-making, so that politicians are probably quick to learn technical jargon from those areas in discourse (esp. in cases where a form like zeitnah(e) does fill a gap in temporal qualification not easily covered by other German expressions). Second, political decision-making itself has over past decades been submitted to change, and has acquired very similar time dynamics (requiring immense flexibility and collaboration amongst the authorities), also making zeitnah(e) in this respect a very suitable temporal modifier for designating political time schedules. And third, politicians who make public speeches and announcements surely have special reasons for treating 'time' with great care and caution when facing the public. Long standing expressions like bald(ig) 'soon' or demnächst 'shortly; very soon' may often serve as unintended cues for displeasure in the audiences, and it is therefore conceivable that alternatives, with technical and efficient connotations from the economy sector clinging to them, are deliberately adopted by politicians to avoid such negative reactions in the public audience on hearing certain events being ("once again!") postponed into the future.

The extension of zeitnah(e) into everyday discourse (not further discussed in this paper) is only a more recent development. A quick search through the internet (Google), for example, yields various 'search requests' for collocations like zeitnahe Rückmeldung 'speedy response', zeitnahe Abmahnung 'speedy warning', zeitnahe Mittelverwendung 'prompt application of funds', zeitnahe Rechnungsstellung 'speedy invoicing' etc., whose precise readings in turn are sometimes discussed publicly in different internet forums. This fact merely proves that people find themselves frequently exposed to this form in everyday situations, literally acquiring its meaning out of sheer communicative necessity in their interaction with public and private institutions (healthcare, customer services, invoicing, working schedules). The fact that native speakers of German, in response to this exposure, now and then also begin to recontexualize this expression further into their own everyday colloquial discourse (e.g., Ich muss meine Kinder zeitnah von der Schule abholen 'I must pick up my kids from school very soon') is thus only the tip of the iceberg, and at this point only marginal in natural discourse. 


\section{Conclusion}

In current linguistic studies, the term 'recontexualization' appears to be mainly reserved for certain types of pragmatic (connotative) change. On the other hand, its application to other processes of semantic-pragmatic change seems less acceptable. My case study on zeitnah(e), however, leads me to reconsider this restricted view and to argue that the concept of (functional) recontexualization deserves to be broadened to include such other processes of change as well, and in particular those which over time lead to functional entrenchment and conventionalization. One argument for this view comes from the empirical observation that zeitnah(e) initially emerged in a very confined space of functional discourse, as a terminus technicus in economical jargon, but subsequently gained currency in other discourse contexts and is increasingly also entering informal speech styles. Another argument is that the meaning change from (A) 'comtemporary' to (B) 'promptly; soon' could not be explained without the consideration of pragmatic context in usage. Whether the tendency towards functional entrenchment and dissociation from the technical jargon will persist is currently unclear. Nevertheless, this past development already demonstrates that the principle of functional recontexualization does not only lead to shifts in pragmatic connotation, but also to semantic-pragmatic change on other levels of meaning evolvement.

\section{Acknowledgements}

I thank the Internal Promotion of Research at Freie Universität Berlin for funding this research (2013-2014) and my colleague Ferdinand von Mengden for his support of my work. Furthermore, I am grateful to Ulrich Detges, Ivo Hajnal and Sonja Zeman for fruitful discussions during the 21. LIPP-Symposium in Munich, 2-4 July 2014.

\section{References}

BWDWB: Brockhaus Wahrig. Deutsches Wörterbuch in sechs Bänden (Volume 6 STE-ZZ). [Brockhaus Wahrig. German dictionary in six volumes (Volume 6 STE-ZZ)] G. Wahrig (Ed.), (1984). Stuttgart: Deutsche-Verlags-Anstalt.

DWDS: Das Digitale Wörterbuch der deutschen Sprache. [The digital dictionary of the German language] http://www.dwds.de

Eichinger, L. M. (2000). Deutsche Wortbildung. Eine Einführung. [German word formation. An Introduction.] Tübingen: Gunter Narr.

Eroms, H. W. (2010). Wörter im Brennpunkt: Die Aktionen „Wort des Jahres“ und „Unwort des Jahres“ als Mittel der Fokussierung öffentlicher Diskurse. [Words in focus: The campaigns 'word of the year' and 'non-word of the year' as means of focusing in public discourses] In R. Harnisch (Ed.), Prozesse sprachlicher Verstärkung (pp. 245-265). Berlin: Walter de Gruyter.

Fill, A. (2010). De-Idiomatisierung und Neu-Idiomatisierung als spannende Sprachstrategien [De-idiomatization and re-idiomatization as exciting strategies of linguistic behavior]. In R. Harnisch (Ed.), Prozesse sprachlicher Verstärkung (pp. 199-211). Berlin: Walter de Gruyter.

Fleischer, W., \& Barz, I. (2012). Wortbildung in der deutschen Gegenwartssprache. [Word formation in the contemporary German language.] (4th ed.). Berlin: Walter de Gruyter. http://dx.doi.org/10.1515/9783110256659

Geyken, A. (2006). The DWDS corpus: A reference corpus for the German language of the 20th century. In C. Fellbaum (Ed.), Collocations and idioms: Linguistic, lexicographic and computational aspects (pp. 23-40). London: Continuum.

GWDS: Das große Wörterbuch der deutschen Sprache in zehn Bänden (Volume 10 Vide-Zz). [The large dictionary of the German language in ten volumes (Volume 10 Vide-Zz)] Dudenredaktion (Eds.), (1999), 3rd ed. Mannheim: Dudenverlag.

Harnisch, R. (2004). Verstärkungsprozesse. Zu einer Theorie der „Sekretion“ und des „Re-konstruktionellen Ikonismus“. Zeitschrift für germanistische Linguistik, 32, 210-232. http://dx.doi.org/10.1515/zfgl.2004.32.2.210

Harnisch, R. (2010). Zu einer Typologie sprachlicher Verstärkungsprozesse. [Towards a typology of linguistic strengthening processes.] In R. Harnisch (Ed.), Prozesse sprachlicher Verstärkung (pp. 3-23). Berlin: Walter de Gruyter. http://dx.doi.org/10.1515/9783110223866.1.3

Heidolph, K. E., Flämig, W., \& Motsch, W. (1981). Grundzüge einer deutschen Grammatik. [Essentials of German grammar.] Berlin: Akademie-Verlag Berlin.

Hopper, P. J. (1987). Emergent grammar. In J. Aske, N. Beery, L. Michaelis, \& H. Filip (Eds.), Berkeley Linguistic Society. Proceedings of the Thirteenth Annual Meeting February 14-16. General Session and Parasession on Grammar and Cognition. (pp. 139-157). Berkeley: Berkeley Linguistic Society. 
Kemmer, S., \& Barlow, M. (2000). Introduction: A usage-based conception of language. In M. Barlow, \& S. Kemmer (Eds.), Usage-based models of language (pp. vii-xxvii). Stanford, CA: CSLI Publications. http://dx.doi.org/10.1093/acprof:oso/9780198259947.003.0001

Levinson, S. C. (2009). Pragmatics (20th ed.). Cambridge: Cambridge University Press.

Lipka, L. (2002). English lexicology. Lexical structure, word semantics \& word-formation. Tübingen: Gunter Narr.

Literature

Sick, B. (2006). Wie nah ist zeitnah? [How near is "zeitnah" [lit. time+near]?] Spiegel Online, 5/5/2006, http://www.spiegel.de/kultur/zwiebelfisch/zwiebelfisch-wie-nah-ist-zeitnah-a-414175.html [2/18/2014]

Traugott, E. C. (2012). The status of onset contexts in the analysis of micro-changes. In M. Kytö (Ed.), English corpus linguistics: Crossing paths (pp. 221-255). Amsterdam: Rodopi. http://dx.doi.org/10.1163/9789401207935_012

Von Mengden, F., \& Coussé, E. (2014). The role of change in usage-based conceptions of language. In E. Coussé, \& F. von Mengden (Eds.), Usage-based approaches to language change. Amsterdam: John Benjamins. http://dx.doi.org/10.1075/sfsl.69.01men

WDG Online: Wörterbuch der deutschen Gegenwartssprache. [Dictionary of Contemporary German] Accessible via http://www.dwds.de

WDG: Wörterbuch der deutschen Gegenwartssprache (1952-1976). [Dictionary of Contemporary German (1952-1976)] R. Klappenbach, \& W. Steinitz (Eds.), (1976). Berlin: Akademie-Verlag Berlin.

Wengeler, M. (2010). Entwicklungsländer, Gastarbeiter, Schwangerschaftsunterbrechung. Formen und Funktionen semantischer Remotivierungen im öffentlich-politischen Sprachgebrauch. [Forms and functions of semantic remotivations in public-political language use.] In R. Harnisch (Ed.), Prozesse sprachlicher Verstärkung (pp. 213-227). Berlin: Walter de Gruyter.

Wiktionary: Ein Wiki-basiertes freies Wörterbuch. [A wiki-based open content dictionary] http://de.wiktionary.org/wiki/Wiktionary:Hauptseite 


\section{Appendix}

Table 1. Data analysis and categorization underlying all entries in Figure 1, Section 2.3.

\begin{tabular}{|c|c|}
\hline $\begin{array}{l}\text { Variants } \\
\text { (cf. §2.3) }\end{array}$ & $\begin{array}{l}\text { Concordances attested in the DWDS corpus DIE ZEIT } \\
\text { (listing by "decade" and "concordance no.") }\end{array}$ \\
\hline VARIANT 1 & 1946-49: --- \\
\hline 'soon’ & 1950-59: --- \\
\hline \multirow[t]{5}{*}{ 'shortly' } & 1960-69: 202 \\
\hline & 1970-79: 197 \\
\hline & $\overline{1980-89}: 161,154$ \\
\hline & 1990-99: $139,136,132,126,122-121$ \\
\hline & 2000-09: $103,101,69,65,48-47,43-42,38-37,33,30,27,25,22-21,17-14,12-11,9,7-4,1$ \\
\hline VARIANT 2 & $\overline{1946-49}: 292-277$ \\
\hline 'contemporary' & 1950-59: $275,272-268,266-257,254-234$ \\
\hline 'modern' & 1960-69: $233-232,230-210,208-203,199-198$ \\
\hline 'time-critical' & $\overline{1970-79}: 196,193-190,188-184,172-162$ \\
\hline \multirow[t]{3}{*}{ 'topical' } & 1980-89: $160,158-155,153-148$ \\
\hline & 1990-99: $147-145,142-141,135-133,129-127,125$ \\
\hline & 2000-09: $104,96,93,75,46,35$ \\
\hline VARIANT 3 & 1946-49: 276 \\
\hline 'close to' & 1950-59: 267 \\
\hline 'prompt(ly)' 'quick(ly)' & 1960-69: $231,201-200$ \\
\hline 'timely' & 1970-79: $195-194,189$ \\
\hline 'short-term' & 1980-89: 159 \\
\hline$\ldots$ & $\begin{array}{l}\frac{1990-99}{2000-09}: 144-143,140,138-137,131-130,124-123 \\
\frac{200-118,116-113,111-109,107-106,102,100,98-97,95-94,91-86,84-82,80-79,}{77-76,74-70,67-66,64-49,45-44,41-39,36,34,32-31,29-28,26,24-23,20-18,13,10,8}\end{array}$ \\
\hline REPETITIONS & 1946-49: --- \\
\hline Numbers in & $\overline{1950-59}: 274-273(272), 255(254)$ \\
\hline brackets ( ) indicate the & $\overline{1960-69}: 209(224), 183-173(184)$ \\
\hline matches which were & 1970-79: --- \\
\hline included in the data & 1980-89: --- \\
\hline analysis (instead of their & 1990-99: --- \\
\hline $\begin{array}{l}\text { repetitions given to the } \\
\text { left) }\end{array}$ & $\begin{array}{l}\text { 2000-09: } 117(118), 112(113), 108(109), 105(106), 99(100), 92(93), 85(84), 81(79), 78(77) \text {, } \\
68(55), 2-3(1)\end{array}$ \\
\hline
\end{tabular}

The entries in Figure 1, Section 2.3, are based on the following data export from the DWDS corpus: DWDS Belegcorpus extrahiert am 06.02.2014, 11:47:13 [DWDS reference corpus extracted 02/06/2014, 11:47:13], DWDS Kerncorpus Version 1.0 [DWDS core corpus version 1.0], Morphologie: TAGH Version [morphology: TAGH version], Tagger: Moot Version, Abfrage [query]: zeitnah \#greater_by_date[9999-12-31,1700-01-01], \#cntxt 1, :zeit01, zeit02, zeit03, zeit04, zeit05, zeit06, zeit07, zeit08, zeit09, zeit10, zeit11, zeit12, zeit13, zeit14, zeit15, Trefferanzahl [total number of concordances]: 292.

\section{(cc) $\mathrm{BY}$}

This work is licensed under a Creative Commons Attribution 3.0 License. 